\title{
EFEKTIVITAS BAHAN AJAR KOMIK TERHADAP HASIL BELAJAR DAN MOTIVASI BELAJAR PESERTA DIDIK KELAS VIII MATERI LINGKARAN DI SMP NEGERI 11 BATAM TAHUN PELAJARAN 2013/2014
}

\author{
Windi Kartika Sari, Fitrah Amelia, Yulian Sari \\ Program Studi Pendidikan Matematika \\ Fakultas Keguruan dan Ilmu Pendidikan(FKIP) \\ Universitas Riau Kepulauan (UNRIKA) Batam
}

\begin{abstract}
ABSTRAK
Penelitian ini dilakukan di SMP Negeri 11 Batam. Hasil belajar matematika dirasa masih rendah dengan ratarata kelas di bawah 70, serta kurangnya motivasi yang diberikan oleh pendidik. Masih banyak pendidik yang menggunakan bahan ajar yang sering digunakan. Perlu adanya bahan ajar yang menarik. Komik merupakan salah satu bahan ajar yang inovatif, variatif, dan menarik. Peran komik memiliki peranan yang sangat penting hal ini komik merupakan media yang tepat untuk proses pembelajaran, karena keterlibatan emosi pembacanya akan sanagt mempengaruhi memori dan daya ingat akan materi pelajaran yang didapatkan. Penelitiaan ini menggunakan metode eksperimen dengan jenis penelitian eksperimen semu. Populasi sasaran adalah kelas VIII 7 sebagai kelas eksperimen dengan memberikan perlakuaan berupa pembelajaran menggunakan bahan ajar komik dan kelas VIII $_{6}$ sebagai kelas kontrol dengan memberikan perlakuan berupa pemberian pelajaran menggunakan bahan ajar yang sering digunakan. Pengambilan sampel pada penelitiaan ini menggunakan teknik Cluster Random Sampling. Data dianalisis dengan teknik analisis statistik deskriptif dan analisis statistik inferensial menggunakan uji t satu pihakpada taraf signifikan $(\alpha)$ 0,05. Berdasarkan perhitungan analisis infrensial hasil belajar dari pengujian hipotesis diperoleh thitung sebesar 3,581 sedangkan perhitungan analisis infrensial hasil belajar dari pengujian hipotesis diperoleh $t_{\text {hitung }}$ sebesar 3,028 dengan nilai tabel sebesar 1,986. Dengan demikian nilai thitung lebih besar dari tabel yang berarti hipotesis nol (Ho) ditolak dan hipotesis alternatif (Ha) diterima. Dapat disimpulkan bahwa terdapat efektifitas bahan ajar komik terhadap hasil belajar dan motivasi belajar peserta didik kelas VIII materi lingkaran di SMP Negeri 11 Batam Tahun Pelajaran 2013/2014.
\end{abstract}

Kata kunci: Komik, Hasi Belajar, Motivasi Belajar, Teknik Cluster Random Sampling.

\section{PENDAHULUAN}

Pendidikan adalah salah satu faktor yang mempengaruhi perkembangan ilmu pengetahuan dan teknologi. Persoalan pendidikan merupakan persoalan yang tidak akan pernah ada akhirnya. Hal terpenting dalam pendidikan adalah upaya yang dilakukan agar kualitas pendidikan semakin lama semakin membaik. Pendidikan yang berkualitas memerlukan aspekaspek yang terkait untuk mendukung perubahan, perbaikan, dan pembaruan yang dapat mempengaruhi keberhasilan pendidikan. Aspek-aspek tersebut meliputi pendidik, peserta didik, kurikulum, serta metode pembelajaran yang digunakan. Karena pendidikan merupakan hak asasi sekaligus hak konstitusional yang dimiliki warga negara dan negara wajib memenuhinya.

Pendidik dan calon pendidik memiliki tanggung jawab yang besar dan perlu diperhatikan secara serius. Kompetensi-kompetensi inti yang harus dan wajib dimiliki oleh seorang pendidik dan dosen diantaranya adalah mengembangkan kurikulum yang terkait 
dengan bidang pengembangan yang dikuasai dan menyelenggarakan kegiatan pengembangan yang mendidik untuk kompetensi pedagogis, serta mengembangkan materi pembelajaran secara kreatif dan dapat memanfaatkan teknologi informasi dan komunikasi untuk berkomunikasi guna perkembangan diri untuk kompetensi profesional. Sehingga pendidik diharuskan mampu menyusun bahan ajar yang inovatif guna menciptakan metode pembelajaran yang menarik dan menyenangkan (Departemen Pendidikan Nasional Direktorat Jendral Manajemen Pendidikan Dasar dan Menengah Direktorat Pembinaan Sekolah Menengah Atas, 2008). Kegiatan pembelajaran di sekolah biasanya hanya menekankan pada transformasi informasi faktual dan pengembangan penalaran yaitu pemikiran logis menuju pencapaian satu jawaban benar atau salah. Menurut Winkel (1991) dalam Sutikno, (2013) mengartikan pembelajaran sebagai seperangkat tindakan yang dirancang untuk mendukung proses belajar peserta didik, dengan memperhitungkan kejadian-kejadian eksternal yang berperan terhadap rangkaian kejadian-kejadian internal yang berlangsung di dalam diri peserta didik.

Matematika adalah pengetahuan dasar yang sangat penting untuk menguasai sains dan teknologi yang diperlukan pada era globalisasi saat ini. Kenyataan yang terjadi, dalam kehidupan sehari-hari tidak ada orang yang terlepas dari Matematika. Termasuk proses belajar dan pembelajaran di sekolah. Namun kenyataan menunjukkan banyaknya keluhan dari peserta didik tentang pelajaran Matematika yang sulit, tidak menarik, dan membosankan. Keluhan tersebut secara langsung maupun tidak langsung akan sangat berpengaruh terhadap hasil belajar Matematika yang rendah pada setiap jenjang pendidikan. Meskipun upaya untuk mengatasi hasil belajar Matematika yang rendah telah dilakukan oleh pemerintah, seperti penyempurnaan kurikulum, pengadaan buku paket, peningkatan pengetahuan pendidik melalui penataran, serta melakukan berbagai penelitian terhadap faktor-faktor yang diduga mempengaruhi hasil belajar Matematika dirasa belum mencapai hasil yang dihrapkan dengan nilai KKM adalah 70. Berdasarkan data yang penulis dapat di SMP Negeri 11 Batam, bahwa hasil belajar Matematika berdasarkan rata-rata nilai uas dirasa masih rendah

Untuk itu pemberian motivasi kepada peserta didik perlu diberikan karena masih banyak pendidik yang menggunakan bahan ajar yang sering digunakan. Bentuk-bentuk bahan ajar yang sering digunakan seperti buku-buku teks (buku paket) jumlah lembar halamannnya banyak terlihat tebal membuat peserta didik malas membaca dan belajar. Peserta didik merasa bosan dan kurang tertarik dalam mengikuti proses pembelajaran, sehingga proses pembelajaran menjadi tidak efisien dan tidak efektif yang berakibat belum optimalnya hasil belajar peserta didik. Melihat peran Matematika yang sangat penting, maka perlu adanya perlakuan khusus 
agar Matematika tidak lagi menjadi pelajaran yang menakutkan, tetapi sebaliknya belajar Matematika adalah suatu hal yang menyenangkan. Peserta didik perlu alat bantu untuk dapat menguasai bahan pelajaran dengan jelas dan sistematis. Bahan ajar yang disampaikan pendidik sering kali tidak berasal dari satu buku, tetapi berasal dari beberapa sumber buku. Terutama bagi peserta didik yang mempunyai kekurangan dalam penerimaan materi secara lisan. Kebiasaan pendidik yang kurang sistematis perlu diimbangi dengan pengelolaan bahan ajar yang dikembangkan sendiri. Pendidik menyadari bahwa pembelajaran yang menarik, efektif, dan efisien membutuhkan bahan ajar yang inovatif. Ketika bahan ajar dibuat oleh pendidik, pembelajaran akan jauh lebih menarik dan mengesankan bagi peserta didik, sehingga kegiatan pembelajaran tidak menjadi membosankan dan tidak menjadi jenuh. Seorang pendidik dan calon pendidik dituntut untuk dapat berfikir kreatif dalam menentukan metode dan cara dalam melaksanakan tugas mengajar peserta didik, agar tercapai dan terpenuhi apa yang menjadi tujuan pembelajaran. Salah satunya adalah dengan menggunakan bahan ajar yang inovatif.

Komik merupakan salah satu bahan ajar yang inovatif, variatif dan menarik dengan memenuhi tingkat kebutuha peserta didik. Peranan komik sebagai bahan ajar mempunyai peranan yang sangat penting yaitu memiliki kemampuan dalam menciptakan minat belajar peserta didik serta mempermudah peserta didik mengingat materi pelajar yang dipelajarinya. Hal ini dipertegas oleh ilmuan saraf, Le Doux (1994), dalam DePorter (2010) yang mengemukakan komik merupakan media yang tepat untuk proses pembelajaran, karena keterlibatan emosi pembacanya akan sangat mempengaruhi memori dan daya ingat akan materi pelajaran yang didapatkan. Dengan menggunakan bahan ajar komik, maka akan tercipta suasana belajar yang menyenangkan dan tidak membosankan baik bagi pendidik maupun peserta didik. Bahan ajar komik diharapkan dapat mempermudah peserta didik memahami materi yang diberikan demi tercapainya tujuan pembelajaran untuk mendapatkan hasil belajaran Matematika yang diharapkan.

Tujuan dalam penelitian ini yaitu: Efektivitas bahan ajar komik terhadap hasil belajar peserta didik kelas VIII pada materi lingkaran di SMP Negeri 11 Batam Tahun Pelajaran 2013/2014 dan Efektivitas bahan ajar komik terhadap motivasi belajar peserta didik kelas VIII pada materi lingkaran di SMP Negeri 11 Batam Tahun Pelajaran 2013/2014.

\section{METODOLOGI PENELITIAN}

Penelitian ini telah dilaksanakan di SMP Negeri 11 Batam. Sedangkan waktu penelitian telah dilaksanakan pada semester II TP 2013/2014. Variabel dalam penelitian ini yaitu variabel terikat $(\mathrm{Y})$ dan variabel bebas $(\mathrm{X})$. Variabel terikat yang menjadi fokus dalam penelitian ini 
adalah hasil belajar matematika $\left(\mathrm{Y}_{1}\right)$ dan motivasi belajar $\left(\mathrm{Y}_{2}\right)$, sedangkan variabel bebas sebagai perlakuan yang diberikan dalam penelitian ini adalah bahan ajar (X) yaitu bahan ajar komik yang merupakan perlakuan pada kelas eksperimen dan bahan ajar yang sering digunakan seperti buku paket yang merupakan perlakuan pada kelas kontrol.

Metode yang digunakan dalam penelitian ini adalah metode eksperimen semu (Quasi Experiment) merupakan rancangan penelitian yang digunakan apabila kontrol tidak sepenuhnya dapat dilakukan (Lubis, 2011), dengan Populasi terjangkau adalah seluruh peserta didik kelas VIII dengan populasi sasaran yaitu kelas $\mathrm{VIII}_{7}$ sebagai kelas eksperimen dengan memberikan perlakuan berupa pembelajaran mengunakan bahan ajar komik dan kelas $\mathrm{VIII}_{6}$ sebagai kelas kontrol dengan memberikan perlakuan berupa pembelajaran mengunakan bahan ajaryang sering digunakan. Jumlah sampel penelitian untuk kelas eksperimen dan kelas kontrol masing-masing berjumlah 41 peserta didik. Pengambilan sampel mengunakan teknik Cluster Random Sampling (Lubis, 2011). Desain penelitian yang digunakan adalah two-group pottest only design, merupakan desain eksperimen yang memiliki dua kelompok data yaitu data posttest kelompok eksperimen dan kelompok kontrol. Data yang dikumpulkan berupa data hasil belajar dengan mengunakan tes dalam bentuk soal objektif (pilihan ganda) dan data berupa motivasi belajar dengan menggunakan non tes dalam bentuk angket yang dilaksanakan setelah kegiatan pembelajaran dilaksanakan.

Sebelum instrumen digunakan, terlebih dahulu dilakukan kalibrasi instrumen tes untuk mendapatkan karakteristik tes yang baik dengan cara memvaliditas dan mereliabilitas tes tersebut. Validitas tes dilakukan dengan validitas secara empiris mengunakan point biserial correlation $\left(\mathrm{r}_{\text {pbis }}\right.$ ) dengan tujuan setiap butir soal memiliki kesahihan secara empirik (Latisman, 2011), sedangkan untuk validitas non tes menggunakan Product Moment (Sugiyono, 2011). Sedangan reliabilitas tes dilakukan dengan perhitungan koefisien reliabilitas mengunakan metode KR-20 (Kuder Ricardson-20) dengan tujuan setiap butir soal yang disusun memiliki keterandalan secara empiris (Sudijono, 2012), sedangkan untuk non tes menggunakan metode alpha cronbach (Sugiyono, 2011).

Kalibrasi instrumen tes dilaksanakan di SMP Negeri 20 Batam yang beralamat di Jalan Gajah Mada Tiban Koperasi Sekupang, Batam. Kalibrasi instrumen tes menggunakan 30 butir soal dalam bentuk tes objektif dan 30 butir pernyataan dalam bentuk angket pada materi pembelajaran lingkaran. Pengambilan populasi dan sampel data untuk kalibrasi instrumen tes objektif dilaksanakan dengan tehnik cluster random sampling. Kalibrasi instrumen tes objektif diperoleh data dari kelas 8,3 yang berjumlah 30 peserta didik. Dari pengujian validitas tes baik secara internal maupun secara empiris mengunakan point biserial correlation $\left(\mathrm{r}_{p b i s}\right)$ dengan 
taraf signifikan $(\alpha)=0,05$ menunjukan 25 butir soal dan Product Moment dengan taraf signifikan $(\alpha)=0,05$ menunjukan 25 butir pernyataan dinyatakan valid. Sedangkan hasil reliabilitas tes dengan mengunakan metode KR-20 (Kuder Ricardson-20) dengan taraf signifikan $(\alpha)=0,05$ diperoleh nilai koefisien reliabilitas instrumen tes objektif sebesar 1,00 yang diinterpretasikan dengan nilai pada tabel $\mathrm{r}$ menunjukan instrumen tes hasil belajar yang disusun memiliki tingkat reliabilitas yang sangat tinggi, sedangkan hasil reliabilitas tes dengan mengunakan metode alpha cronbach dengan taraf signifikan $(\alpha)=0,05$ diperoleh nilai koefisien reliabilitas instrumen tes objektif sebesar 0,917 yang diinterpretasikan dengan nilai pada tabel $r$ menunjukan instrumen tes hasil belajar yang disusun memiliki tingkat reliabilitas yang sangat tinggi.

Data penelitian dianalisis dengan statistik deskriptif dan inferensial. Analisis statistik deskriptif secara umum digunakan untuk menyajikan data dalam distribusi frekuensi yang divisualisasikan dalam bentuk histogram. Analisis statistik inferensial dilakukan untuk pengujian hipotesis dan generalisasi hasil penelitian. Sebelum melakukan pengujian hipotesis terlebih dahulu dilakukan uji prasyarat, berupa uji normalitas dan uji homogenitas. Uji normalitas mengunakan uji liliefors dan uji homogenitas mengunakan uji f(Siregar, 2013).

Pengujian hipotesis dilakukan dengan mengunakan uji t satu pihak dengan rumus separated varians (Sugiyono, 2011) untuk membuktikan pengaruh bahan ajar komik terhadap peningkatan hasil belajar dan motivasi belajar. Pengolahan data dilakukan menggunakan program microsoft excel. Karena uji statistik yang digunakan adalah uji statistik dua sampel independent, maka hipotesis yang diuji secara statistik dirumuskan sebagai berikut:

$$
\begin{aligned}
& \text { Ho : } \mu_{1}=\mu_{2} \\
& \text { Нa }: \mu_{1} \neq \mu_{2}
\end{aligned}
$$

\footnotetext{
Keterangan:

Ho $=$ Hipotesis nol

$\mathrm{Ha}=$ Hipotesis alternatif

$\mu_{1} \quad=$ Rata-rata nilai kelompok eksperimen

$\mu_{2} \quad=$ Rata-rata nilai kelompok kontrol
}

\section{HASIL DAN PEMBAHASAN}

Hasil penelitian dan pembahasan diuraikan dari hasil analisis statistik deskriptif dan statistik inferensial. Hasil analisis statistik deskriptif dipaparkan pada deskripsi data dari kelas eksperimen maupun kelas kontrol. Sedangkan hasil analisis statistik inferensial dipaparkan 
pada uji hipotesis dengan mengunakan uji t. Siregar (2013) mengemukakan deskripsi data adalah deskripsi yang mengambarkan karakteristik atau ukuran sekelompok data yang dianalisis mengunakan teknik statistik deskriptif yang bertujuan memperoleh gambaran umum mengenai data yang diukur. Teknik analisis yang digunakan untuk mendeskripsikan data adalah ukuran pemusatan data (tendensi sentral) dan ukuran penyebaran data (tendensi penyebaran). Hasil belajar sebagai suatu pencapaian peserta didik terhadap kompetensi pemahaman mengenai materi lingkaran diperoleh berdasarkan proses pembelajaran. Tes hasil belajar berbentuk tes pilihan ganda dengan skor dikotomi. Rentang nilai teoritis hasil belajar yaitu 0-100. Rekapitulasi perhitungan statistik deskriptif secara keseluruhan sampel disajikan pada tabel 1 .

Tabel 1. Rekapitulasi data statistik keseluruhan data sampel penelitian hasil belajar

\begin{tabular}{|c|c|c|c|c|c|c|c|c|c|c|c|}
\hline \multirow{2}{*}{$\begin{array}{l}\mathbf{N} \\
\mathbf{O}\end{array}$} & \multirow{2}{*}{$\begin{array}{l}\text { PERLAKUA } \\
\mathbf{N}\end{array}$} & \multicolumn{5}{|c|}{ DATA PENELITIAN } & \multicolumn{3}{|c|}{$\begin{array}{l}\text { TENDENSI } \\
\text { SENTRAL }\end{array}$} & \multicolumn{2}{|c|}{$\begin{array}{l}\text { TENDENSI } \\
\text { PENYEBARA } \\
\mathbf{N}\end{array}$} \\
\hline & & $\mathbf{n}$ & $\sum \mathbf{X}$ & $\mathbf{X}_{\text {MaX }}$ & $\mathbf{X}_{\text {MIN }}$ & $\mathbf{r}$ & $\overline{\mathbf{X}}$ & $\begin{array}{l}\text { M } \\
\text { e }\end{array}$ & $\begin{array}{l}\mathbf{M} \\
\mathbf{0}\end{array}$ & $\mathbf{S}^{2}$ & $\mathbf{S}$ \\
\hline 1 & $\begin{array}{l}\text { Bahan Ajar } \\
\text { Komik }\end{array}$ & $\begin{array}{l}4 \\
1 \\
\end{array}$ & $\begin{array}{l}338 \\
8\end{array}$ & 96 & 60 & $\begin{array}{l}3 \\
6 \\
\end{array}$ & 83 & 84 & 88 & 109,29 & 10.45 \\
\hline 2 & $\begin{array}{l}\text { Bahan Ajar } \\
\text { Konvensional }\end{array}$ & $\begin{array}{l}4 \\
1\end{array}$ & $\begin{array}{l}318 \\
8\end{array}$ & 96 & 60 & $\begin{array}{l}3 \\
6\end{array}$ & 78 & 76 & 76 & 93,64 & 9,68 \\
\hline
\end{tabular}

\begin{tabular}{lll}
\multicolumn{2}{l}{ Keterangan } & \\
$\mathrm{n}$ & $=$ & Jumlah sampel \\
$\sum \mathrm{X}=$ & Jumlah Keseluruhan Data sampel Penelitian \\
$\overline{\mathrm{X}}=$ & Rata-Rata Data Sampel Penelitian \\
$\mathrm{Xmax}=$ & Data Terbesar (Nilai Tertingi) \\
$\mathrm{Xmin}$ & $=$ & Data Terkecil (Nilai Terendah) \\
$\mathrm{Mo}$ & $=$ & Modus \\
$\mathrm{Me}$ & $=$ & Median \\
$\mathrm{r}$ & $=$ & Rentang (Range) \\
$\mathrm{S}$ & $=$ & Standar Deviasi \\
$\mathrm{S}^{2}$ & $=$ & Varians
\end{tabular}

Secara umum terlihat bahwa keseluruhan peserta didik kelas VII SMP Negari 11 Batam yang mengikuti proses pembelajaran mengunakan bahan ajar komik sebanyak 41 peserta didik diperoleh nilai tertinggi 96, nilai terendah 60, sedangkan hasil belajar mengunakan bahan ajar 
yang sering digunakan menunjukan data dengan jumlah sampel penelitian sebanyak 41 peserta didik diperoleh nilai tertinggi 96, nilai terendah 60, dengan demikian hasil belajar mengunakan bahan ajar komik lebih baik dibandingakan mengunakan bahan ajar yang sering digunakan. Secara umum distribusi frekuensi data hasil penelitian tiap-tiap kelompok perlakuan dapat dilihat pada gambar 1 .

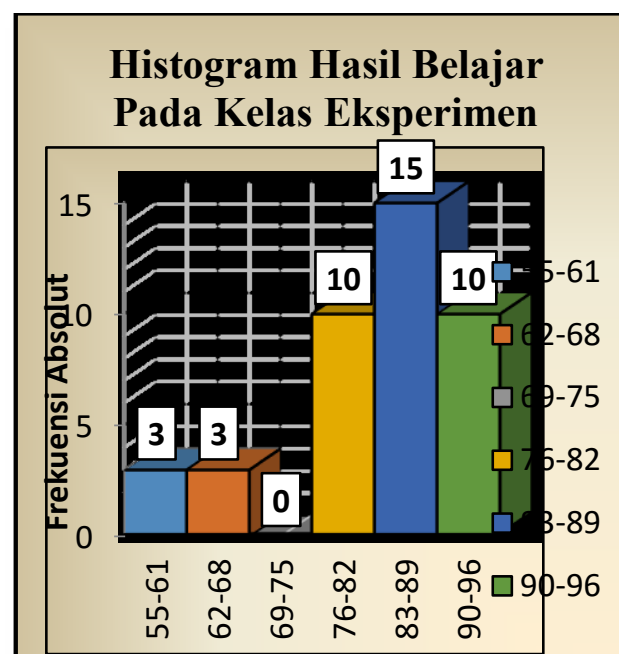

Kelas Interval

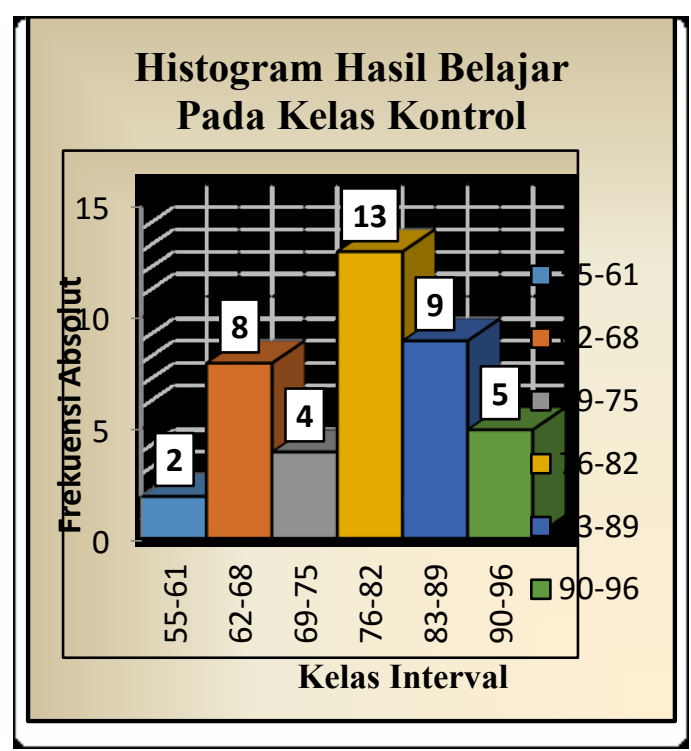

Gambar. 1 Histogram Hasil Belajar Tiap-Tiap Kelompok Perlakuan

Hasil belajar sebagai suatu pencapaian peserta didik terhadap kompetensi pemahaman mengenai materi lingkaran diperoleh berdasarkan proses pembelajaran. Motivasi belajar berbentuk angket dengan skor skala likert. Rentang nilai teoritis hasil belajar yaitu 1-4. Rekapitulasi perhitungan statistik deskriptif secara keseluruhan sampel disajikan pada tabel 2.

Tabel 2. Rekapitulasi data statistik keseluruhan data sampel penelitian motivasi belajar

\begin{tabular}{|c|c|c|c|c|c|c|c|c|c|c|c|}
\hline \multirow{2}{*}{ NO } & \multirow{2}{*}{ PERLAKUAN } & \multicolumn{5}{|c|}{ DATA PENELITIAN } & \multicolumn{3}{|c|}{$\begin{array}{l}\text { TENDENSI } \\
\text { SENTRAL }\end{array}$} & \multicolumn{2}{|c|}{$\begin{array}{l}\text { TENDENSI } \\
\text { PENYEBARAN }\end{array}$} \\
\hline & & $\mathbf{n}$ & $\sum \mathbf{X}$ & $\mathbf{X}_{\text {MAX }}$ & $\mathbf{X}_{\text {MIN }}$ & $\mathbf{r}$ & $\overline{\mathbf{X}}$ & Me & Mo & $\mathbf{S}^{2}$ & $\mathbf{S}$ \\
\hline 1 & $\begin{array}{l}\text { Bahan Ajar } \\
\text { Komik }\end{array}$ & 41 & 3460 & 96 & 72 & 24 & 84 & 84 & 84 & 47,04 & 6,86 \\
\hline 2 & $\begin{array}{l}\text { Bahan Ajar } \\
\text { Konvensional }\end{array}$ & 41 & 3256 & 96 & 68 & 28 & 79 & 80 & 80 & 63,65 & 7,98 \\
\hline
\end{tabular}

$\begin{array}{lll}\text { Keterangan } & : \\ \mathrm{n} & = & \text { Jumlah sampel } \\ \sum \mathrm{X} & = & \text { Jumlah Keseluruhan Data sampel Penelitian } \\ \mathrm{X} & = & \text { Rata-Rata Data Sampel Penelitian } \\ \mathrm{Xmax} & = & \text { Data Terbesar (Nilai Tertingi) } \\ \mathrm{Xmin} & = & \text { Data Terkecil (Nilai Terendah) } \\ \mathrm{Mo} & = & \text { Modus } \\ \mathrm{Me} & = & \text { Median }\end{array}$




$\begin{array}{lll}\mathrm{r} & = & \text { Rentang (Range) } \\ \mathrm{S} & = & \text { Standar Deviasi } \\ \mathrm{S}^{2} & = & \text { Varians }\end{array}$

Secara umum terlihat bahwa keseluruhan peserta didik kelas VIII SMP Negari 11 Batam yang mengikuti proses pembelajaran mengunakan bahan ajar komik sebanyak 41 peserta didik diperoleh nilai tertinggi 96, nilai terendah 72, sedangkan hasil belajar mengunakan bahan ajar yang sering digunakan dengan jumlah sampel penelitian yang sama banyak diperoleh nilai tertinggi 96, nilai terendah 68, dengan demikian motivasi belajar mengunakan bahan ajar komik lebih baik dibandingakn mengunakan bahan ajar yang sering digunakan. Secara umum distribusi frekuensi data hasil penelitian tiap-tiap kelompok perlakuan dapat dilihat pada gambar 2 .

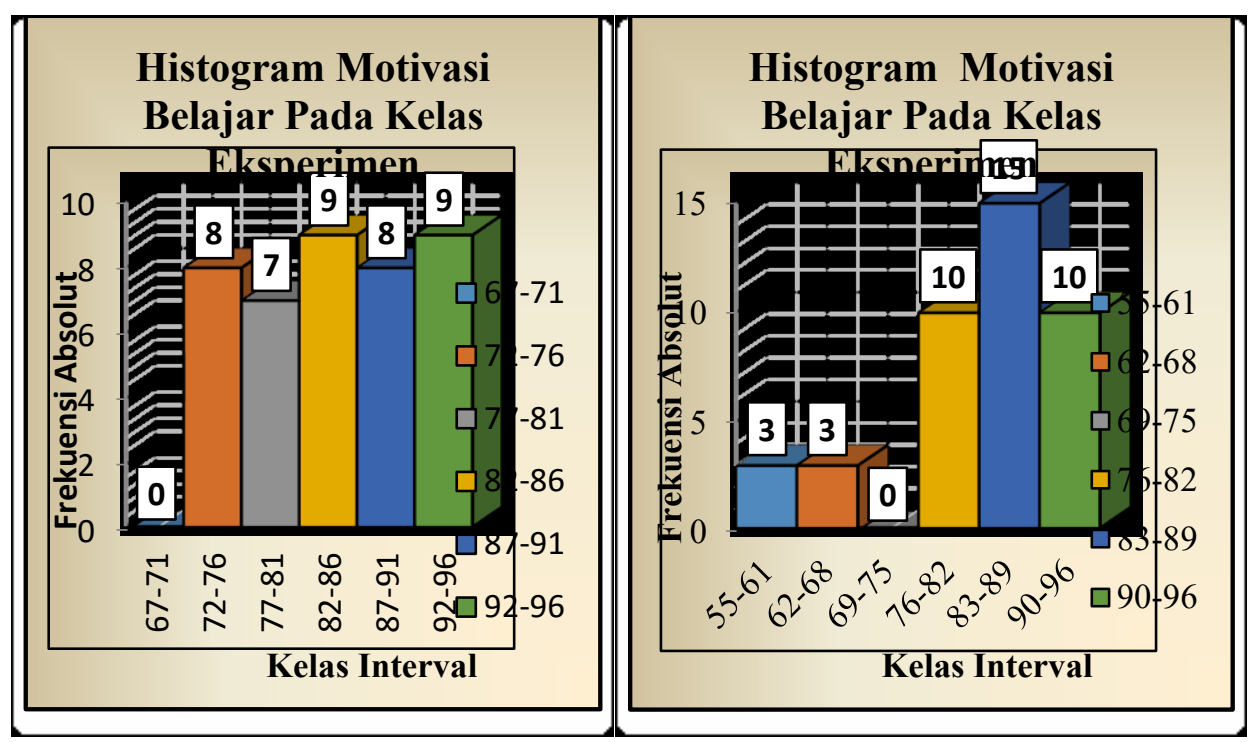

Gambar 2. Histogram Motivasi Belajar Tiap-Tiap Kelompok Perlakuan

Analisis statistik inferensial untuk melakukan uji terhadap hipotesis penelitian yang diajukan. Sebelum melakukan uji hipotesis, data hasil penelitian harus berdistribusi normal dan populasinya homogen. Prasyarat uji normalitas dilakukan dengan menggunakan uji lilifors dan uji homogenitas populasi menggunakan uji Barlett. Uji normalitas dilakukan untuk melihat normal atau tidaknya sebaran data yang akan dianalisis dari setiap kelompok perlakuan penelitian. Uji normalitas dilakukan dengan menggunakan uji liliefors pada taraf signifikansi $(\alpha)=0,05$.

Berdasarkan hasil perhitungan uji normalitas untuk hasil belajar menggunakan uji Liliefors, untuk kelompok perlakuan pembelajaran dengan menggunakan bahan ajar komik diperoleh nilai $\mathrm{L}$ hitung sebesar 0,132 dan untuk kelompok perlakuan pembelajaran dengan menggunakan bahan ajaryang sering digunakan diperoleh nilai $\mathrm{L}_{\text {hitung }}$ sebesar 0,127 , sedangkan nilai kritis $\mathrm{L}_{\text {tabel }}$ pada taraf signifikan $(\alpha)=0,05$ sebesar 0,138 , karena nilai $\mathrm{L}_{\text {hitung }}$ 
untuk setiap kelompok perlakuan lebih kecil dibandingkan nilai kritis $\mathrm{L}_{\text {tabel}}$, maka hipotesis nol (Ho) diterima, berarti data dari kedua kelompok perlakuan berdistribusi normal sedangkan hasil perhitungan uji normalitas untuk motivasi belajar menggunakan uji Liliefors, untuk kelompok perlakuan pembelajaran dengan menggunakan bahan ajar komik diperoleh nilai L hitung sebesar 0,108 dan untuk kelompok perlakuan pembelajaran dengan menggunakan bahan ajaryang sering digunakan diperoleh nilai $\mathrm{L}_{\text {hitung }}$ sebesar 0,108 , sedangkan nilai kritis $\mathrm{L}_{\text {tabel }}$ pada taraf signifikan $(\alpha)=0,05$ sebesar 0,138 , karena nilai L $L_{\text {hitung }}$ untuk setiap kelompok perlakuan lebih kecil dibandingkan nilai kritis $\mathrm{L}_{\text {tabel, }}$ maka hipotesis nol (Ho) diterima, berarti data dari kedua kelompok perlakuan berdistribusi normal dan uji dapat dilanjutkan untuk melihat homogenitas asal populasi kelompok data.

Setelah prasyarat normalitas terpenuhi, selanjutnya dilakukan pengujian homogenitas data hasil penelitian. Pengujian homogenitas dilakukan untuk menganalisis data untuk setiap kelompok perlakuan penelitian berasal dari populasi yang sama atau homogen. Uji homogenitas populasi hasil belajar dilakukan dengan menggunakan uji $\mathrm{F}$ pada taraf signifikan $(\alpha)=0,05$. Hasil perhitungan homogenitas diperopeh nilai $F$ hitung $\left(F_{\text {hitung }}\right)$ sebesar 0,70 sedangkan nilai chi-kuadrat tabel $\left(\mathrm{F}_{\text {tabel }}\right)$ pada taraf signifikan $\alpha=0,05$. Sebesar $=1,69$. Karena nilai $\mathrm{F}$ hitung $\left(\mathrm{F}_{\text {hitung }}\right)$ lebih kecil dariF tabel $\left(\mathrm{F}_{\text {tabel }}\right)$ maka pengujian menerima hipotesis nol (Ho), sehingga disimpulkan bahwa data dari kedua kelompok perlakuan bersifat homogen dan berasal dari populasi yang sama,selanjutnya Uji homogenitas populasi motivasi belajar dilakukan dengan menggunakan uji $\mathrm{F}$ pada taraf signifikan $(\alpha)=0,05$. Hasil perhitungan homogenitas diperopeh nilai $\mathrm{F}$ hitung $\left(\mathrm{F}_{\text {hitung }}\right)$ sebesar 1,35 sedangkan nilai chi-kuadrat tabel $\left(F_{\text {tabel }}\right)$ pada taraf signifikan $\alpha=0,05$. Sebesar $=1,69$. Karena nilai $F$ hitung $\left(F_{\text {hitung }}\right)$ lebih kecil dariF tabel $\left(\mathrm{F}_{\text {tabel }}\right)$ maka pengujian menerima hipotesis nol (Ho), sehingga disimpulkan bahwa data dari kedua kelompok perlakuan bersifat homogen dan berasal dari populasi yang sama dengan demikian perlakuan penelitian telah memenuhi persyaratan analisis untuk menguji hipotesis.

Uji Hipotesis dilakukan dengan teknik analisis statistik inferensial bertujuan mengkaji, menaksir dan mengambil kesimpulan berdasarkan data yang diperoleh dari sampel untuk mengambarkan karakteristik atau ciri dari suatu populasi. Teknik analisis statistik inferensial dilakukan dengan mengunakan uji t karena data homogen, berdistribusi normal dan kelas yang digunakan sebanyak 2 kelas yaitu kelas eksperimen dan kontrol serta hubungan variabel bebas dan terikat bersifat parsial serta standar deviasi belum diketahui. Uji $\mathrm{t}$ dalam penelitian ini bertujuan untuk membuktikan terdapat atau tidaknya pengaruh bahan ajar komik dalam 
meningkatan hasil belajar dan motivasi belajar peserta didik kelas VIII pada materi lingkaran di SMP Negeri 11 Batam Tahun Pelajaran 2013/2014.

Pengujian hipotesis dilakukan untuk melihat adanya pengaruh perlakuan dari kedua kelas (kelompok perlakuan) dengan cara membandingkan rata-rata kedua kelompok data mengunakan uji t dengan taraf signifikan $(\alpha)=0.05$. Rekapitulasi hasil perhitungan uji t hasil belajar antar kelompok perlakuan penelitian pada taraf signifikansi $(\alpha)=0,05$. Berdasarkan uji t satu pihak diperoleh nilai $t_{\text {hitung }}$ dari perbandingan rata-rata antar kelompok perlakuan sebesar 3,581 sedang nilai $t_{\text {tabel }}$ uji $t$ satu pihak pada taraf signifikan $(\alpha=0,05)$ dengan jumlah sampel setiap kelompok perlakuan (n) sebanyak 80 peserta didik diperoleh sebesar 1,986. Karena nilai $t_{\text {hitung }}$ lebih besar dari $t_{\text {tabel }}$ maka pengujian menolak hipotesis nol (Ho). Hasil penelitian menerima hasil hipotesis alternatif (Ha), sehingga terdapatnya efektivitas bahan ajar komik terhadap peningkatan hasil belajar peserta didik kelas VIII pada materi lingkaran di SMP Negeri 11 Batam TP 2013/2014.Sedangkan rekapitulasi hasil perhitungan uji t motivasi belajar antar kelompok perlakuan penelitian pada taraf signifikansi $(\alpha)=0,05$. Berdasarkan uji t satu pihak diperoleh nilai thitung dari perbandingan rata-rata antar kelompok perlakuan sebesar 3,028 sedang nilai tabel uji t satu pihak pada taraf signifikan $(\alpha=0,05)$ dengan jumlah sampel setiap kelompok perlakuan (n) sebanyak 80 peserta didik diperoleh sebesar 1,986. Karena nilai thitung lebih besar dari $t_{\text {tabel }}$ maka pengujian menolak hipotesis nol (Ho). Hasil penelitian menerima hasil hipotesis alternatif (Ha), sehingga terdapatnya Efektivitas bahan ajar komik terhadap peningkatan motivasi belajar peserta didik kelas VIII pada materi lingkaran di SMP Negeri 11 Batam TP 2013/2014.

Mulyatiningsih (2012) menyatakan dalam penelitian eksperimen, pengaruh memberi makna terdapat perubahan atau peningkatan sebagai akibat adanya perlakuan maka perlakuan tersebut dinyatakan memberi pengaruh. Pengaruh bisa dibuktikan dari hasil kelompok yang diberi perlakuan lebih tinggi dari kelompok yang tidak diberi perlakuan atau ada peningkatan sebelum dan sesudah perlakuan. Dari pernyataan Mulyatiningsih (2012) dan hasil analisis secara deskriptif serta hasil analisis secara inferensial (uji hipotesis) membuktikan terdapat efektivitas bahan ajar komik terhadap peningkatan hasil belajar dan motivasi belajar peserta didik kelas VIII SMP Negeri 11 Batam pada materi lingkaran TP 2013/2014. Hasil penelitian membuktikan bahwa peserta didik yang mengikuti pembelajaran dengan menggunakan bahan ajar komik pencapaian hasil belajar lebih baik dari peserta didik yang mengikuti pembelajaran mengunakan bahan ajar yang sering digunakan, ini berarti pembelajaran dengan bahan ajar komik memberikan pengaruh dalam meningkatkan hasil belajar berupa keterampilan proses peserta didik. 
Hal tersebut juga sesuai dengan beberapa hasil penelitian yang relevan menunjukan terjadinya peningkatan hasil belajar mengunakan bahan ajar komik, beberapa penelitian yang relevan berdasarkan penelitian Fitri Apriyani dkk, (2012) hasil penelitian menyatakan bahwa kelas eksperimen yang menggunakan komik memiliki rata-rata hasil post-tes $(75,71)$ yang lebih tinggi dibandingkan kelas kontrol yang tidak menggunakan komik (57,90). Hasil uji hipotesis pada taraf nyata $\alpha=0,05$ dan $\mathrm{dk} 57$, didapatkan harga $\mathrm{t}_{\text {hitung }}>\mathrm{t}_{\text {tabel }}$ yaitu 3,83>1,6785. Dengan demikian berarti pembelajaran dengan memanfaatkan media komik matematika member pengaruhyang besar terhadap tingginya hasil belajar siswa kelas V SD Negeri 24 Pontianak Tenggara.

Berdasarkan uraian di atas maka bahan ajar komik efektif terhadap peningkatan hasil belajar dan motivasi belajar peserta didik kelas VIII pada materi lingkaran di SMP Negeri 11 Batam Tahun pelajaran 2013/2014. Hal ini terbukti dari analisis data secara deskriptif maupun analisis secara inferensial dan didukung penelitian yang relevan mengenai hasil belajar yang memberikan pengaruh positif dengan mengunakan bahan ajar komik dalam proses pembelajaran.

\section{KESIMPULAN DAN SARAN}

Berdasarkan hasil pengujian hipotesis dan pembahasan secara keseluruhan, diperoleh kesimpulan dari penelitian ini yaitu: Terdapat efektivitas bahan ajar komik terhadap hasil belajar peserta didik kelas VIII materi lingkaran di SMP Negeri 11 Batam tahun pelajaran 2013/2014. Terdapat efektivitas bahan ajar komik terhadap motivasi belajar peserta didik kelas VIII materi lingkaran di SMP Negeri 11 Batam tahun pelajaran 2013/2014..

Berdasarkan hasil penelitian ini dapat disarankan bahwa pendidik diharapkan mampu menggunakan bahan ajar yang dalam proses pembelajaran. Sehingga peserta didik lebih tertarik untuk mengikuti proses pembelajaran.

\section{DAFTAR PUSTAKA}

Depdiknas. 2008. Panduan Pengembangan Bahan Ajar. Jakarta: Depdiknas.

DePorter, B. dkk. 2010. Quantum Teaching. Bandung: Kaifa.

Latisman, Dj. 2011. Evaluasi Pendidikan. Padang: UNP Press Padang.

Lubis, S. 2011. Metodologi Penelitian Pendidikan. Padang: Suka Bina Press.

Mulyatiningsih, E. 2013. Metodel Penelitian Terapan Bidang Pendidikan. Cetakan ke-1. Bandung: Alfabet. 
Siregar, S. 2013. Statistik Parametrik untuk Penelitian Kuantitatif Dilengkapi dengan Perhitungan Manual dan Aplikasi SPSS Versi 17. Jakarta: Bumi Aksara.

Sudijono, A. 2012. Pengantar Evaluasi Pendidikan. Cetakan ke-12. Jakarta: Rajawali Press.

Sugiyono. 2011. Statistik untuk Penelitian. Cetakan ke-19. Bandung: Alfabeta. 